\author{
MARCIN DOROCHOWICZ \\ ORCID: 0000-0003-2750-712X \\ Uniwersytet Mikołaja Kopernika w Toruniu \\ HUBERT ŻURKIEWICZ \\ ORCID: 0000-0003-3119-8411 \\ Uniwersytet Mikołaja Kopernika w Toruniu
}

\title{
REALIZACJA NIEKTÓRYCH ZASAD PRAWIDŁOWEGO PRAWODAWSTWA PRZY TWORZENIU WYBRANYCH FORM OCHRONY PRZYRODY
}

\begin{abstract}
Abstrakt: Ustanowienie form ochrony przyrody musi następować zgodnie z zasadą prawidłowego prawodawstwa. Celem niniejszego opracowania jest ustalenie, w jaki sposób prawodawca winien tę powinność realizować. Obejmuje to konieczność ustalenia i udokumentowania (poprzez fotografie oraz opinie biegłego), czy spełniona została przesłanka materialna zawarta w odpowiednim upoważnieniu ustawowym. Następnie, czy utworzenie formy ochrony przyrody jest konieczne dla ochrony przyrody i poszczególnych celów przypisanych przez ustawę konkretnej formie ochrony, a w szczególności, czy nie wystarczą środki ekonomiczne, perswazyjne, organizacyjne albo mniej dolegliwa forma ochrony lub mniejszy jej zakres terytorialny i mniejszy zakres zakazów. Ustalenia te winno się zawrzeć w uzasadnieniu odpowiedniego aktu prawa miejscowego. Redagując z kolei sam tekst aktu normatywnego, konieczne jest precyzyjne ustalenie granic terytorialnych formy ochrony przyrody.

Słowa kluczowe: ochrona przyrody, poprawne prawodawstwo, przyzwoite prawodawstwo, proporcjonalność, precyzja
\end{abstract}

\section{WSTĘP}

$\mathrm{Na}$ organach administracji publicznej spoczywa - wynikający z art. 4 ustawy z dnia 16 kwietnia 2004 roku o ochronie przyrody ${ }^{1}$ (dalej: u.o.p. lub ustawa) — obowiązek dbałości o przyrodę oraz zapewnienia warunków prawnych dla jej ochrony. Formami ochrony przyrody są parki narodowe, rezerwaty przyrody, parki krajobrazowe, obszary chronionego krajobrazu, obszary Natura 2000, pomniki przyrody, stanowiska dokumentacyjne, użytki ekologiczne, zespoły przyrodniczo-

1 Dz.U. z 2020 r. poz. 55. 
-krajobrazowe oraz ochrona gatunkowa roślin, zwierząt i grzybów (art. 6 ust. 1 u.o.p.). Ustanowienie form ochrony przyrody następuje, co do zasady, w aktach prawa miejscowego w postaci odpowiednio: zarządzenia regionalnego dyrektora ochrony środowiska ${ }^{2}$, uchwały sejmiku województwa ${ }^{3}$ albo uchwały rady gminy ${ }^{4}$.

Ustawa określa przesłanki materialne wydania tych aktów prawa miejscowego, wymogi uzyskania odpowiednich uzgodnień i opinii ${ }^{5}$ oraz zakres spraw przekazanych do uregulowania, który - choć wymieniany osobno dla poszczególnych grup form ochrony przyrody ${ }^{6}$ - jest podobny w odniesieniu do wszystkich. Wskazuje formy ochrony przyrody, obowiązywanie obszarowe danego aktu (bliżej omówiono to przy precyzji aktu), cele ochrony ${ }^{7}$, podmiot sprawujący nadzór ${ }^{8}$ oraz zakazy właściwe spośród wymienionych $\mathrm{w}$ ustawie ${ }^{9}$, na przykład budowy lub przebudowy infrastruktury budowlanej i urządzeń technicznych (art. 15 ust. 1 pkt 1 u.o.p.). W akcie prawa miejscowego, które dotyczy obszarów chronionego krajobrazu, uregulować trzeba także ustalenia dotyczące czynnej ochrony ekosystemów (art. 23 ust. 2 u.o.p.), a w odniesieniu do rezerwatu przyrody — rodzaj rezerwatu (art. 13 ust. 3 u.o.p.).

Akty normatywne tworzące formy ochrony przyrody podlegają kontroli sądu administracyjnego co do ich zgodności z prawem (art. $1 \S 1$ ustawy z dnia 25 lipca 2002 roku - Prawo o ustroju sądów powszechnych ${ }^{10}$ w zw. z art. $3 \S 2$ pkt 5 ustawy z dnia 30 sierpnia 2002 roku — Prawo o postępowaniu przed sądami administracyjnymi ${ }^{11}$, dalej: p.p.s.a.). Kontrola ta nie jest jedynie oceną formalną, ograniczającą się do stwierdzenia czy przepisy dopuszczają możliwość wydania określonego aktu stanowienia prawa ${ }^{12}$. Jednym z najczęściej przywoływanych wzorców kontroli jest art. 2 Konstytucji Rzeczypospolitej Polskiej z dnia 2 kwietnia 1997 roku (dalej: Konstytucja) ${ }^{13}$. Oczywistą powinnością prawodawcy w państwie prawnym jest bowiem tworzenie „,dobrego prawa"14. Brak przy tym opraco-

2 Dotyczy rezerwatu przyrody. Zob. art. 13 ust. 3 u.o.p.

3 Dotyczy parku krajobrazowego i obszaru chronionego krajobrazu. Zob. art. 23 ust. 2 u.o.p.

${ }^{4}$ Dotyczy pomnika przyrody, stanowiska dokumentacyjnego, użytku ekologicznego i zespołu przyrodniczo-krajobrazowego. Zob. art. 44 ust. 1 u.o.p.

5 Art. 10 ust. 2, art. 13 ust. 3c, art. 16 ust. 4 i art. 44 ust. 3 a u.o.p.

6 To jest rezerwatu przyrody, parku krajobrazowego, obszaru chronionego krajobrazu oraz łącznie: pomnika przyrody, stanowiska dokumentacyjnego, użytku ekologicznego, zespołu przyrodniczo-krajobrazowego. Zob. art. 13 ust. 3, art. 16 ust. 3, art. 23 ust. 2 i art. 44 ust. 2 u.o.p.

7 Z wyjątkiem obszaru chronionego krajobrazu. Zob. art. 23 ust. 2 u.o.p.

${ }^{8} \mathrm{Z}$ wyjątkiem parku krajobrazowego. Zob. art. 16 ust. 3 u.o.p.

9 Z wyjątkiem rezerwatu przyrody, w którym jako najgłębszej spośród omawianych formy ochrony przyrody obowiązują wszystkie zakazy wymienione w ustawie. Zob. art. 15 ust. 1 u.o.p.

10 Dz.U. z 2018 r. poz. 2107.

11 Dz.U. z 2019 r. poz. 2325.

12 Wyrok Naczelnego Sądu Administracyjnego z dnia 30 lipca 2010 roku, sygn. II OSK 1053/ 10 , niepubl.

13 Dz.U. z 1997 r. Nr 78, poz. 483 ze zm.

14 S. Wronkowska, Komentarz do Zasad techniki prawodawczej, Warszawa 2012, s. 7. 
wań przedstawiających, w jaki sposób prawodawca narazić się może na zasadny zarzut jego naruszenia, a także jak może go uniknąć. Autor podejmuje to zagadnienie w niniejszym opracowaniu, odwołując się głownie do orzecznictwa Trybunału Konstytucyjnego i sądów administracyjnych, a także do poglądów doktryny.

Z uwagi na swój szczególny charakter tworzenie parków narodowych — polegające na ich kreacji w drodze ustawy zawierającej jednocześnie dyrektywy ich tworzenia, a potem określaniu i zmienianiu ich granic rozporządzeniem Rady Ministrów ${ }^{15}$ - pozostaje poza polem badań. Podobnie obszary Natura 2000, jako tworzone na podstawie prawa Unii Europejskiej, oraz ochrona gatunkowa roślin, zwierząt i grzybów, z uwagi na swój specyficzny charakter i tworzenie, co do zasady, w drodze rozporządzenia (art. 48-50 u.o.p.).

\section{UDOKUMENTOWANIE PRZESŁANKI MATERIALNEJ I PRZYDATNOŚĆ AKTU WYKONAWCZEGO}

Utworzenie formy ochrony przyrody godzić będzie najczęściej w prawo niezwykle doniosłe - prawo własności ${ }^{16}$. Wyznaczenie granicy dopuszczalnej weń ingerencji odbywa się między innymi w oparciu o zasadę proporcjonalności ${ }^{17}$. Zasada ta, wypracowana na gruncie prawa niemieckiego i następnie przejęta przez inne systemy prawne, a także funkcjonująca w prawie Unii Europejskiej, międzynarodowych i europejskich standardach ochrony praw człowieka, została uznana za obowiązującą także w polskim porządku prawnym jeszcze przed wejściem w życie Konstytucji z 1997 roku. Wówczas „tekstowym oparciem” zasady proporcjonalności była zasada demokratycznego państwa prawnego ${ }^{18}$. Obowiązująca Konstytucja stanowi expressis verbis, że ograniczenia w zakresie korzystania z konstytucyjnych wolności i praw mogą być ustanawiane tylko w ustawie i tylko wtedy, gdy są konieczne w demokratycznym państwie (między innymi dla ochrony środowiska), i że nie mogą one naruszać istoty wolności i praw (art. 31 ust. 3). Nie budzi wątpliwości, że przyroda jest jednym z immanentnych elementów środowiska. Proporcjonalność jest rozumiana jako suma trzech zasad składowych: zasady przydatności, zasady konieczności oraz zasady proporcjonalności sensu stricto, to znaczy zakazu nadmiernej ingerencji ${ }^{19}$. Jednostka powinna mieć możli-

15 Art. 8a ust. 2 i art. 10 ust. 1 u.o.p.

16 A. Lipiński, Glosa do wyroku WSA z dnia 28 września 2018 roku, II SA/Ol 451/10, „Przegląd Prawa Ochrony Środowiska” 2012, nr 4, s. 63 oraz A. Królczyk, Glosa do wyroku NSA z 30 lipca 2010 roku, II OSK 1053/10, „Gdańskie Studia Prawnicze. Przegląd Orzecznictwa” 2011, nr 1, s. 57.

17 Wyrok Trybunału Konstytucyjnego z dnia 31 stycznia 2013 roku, sygn. K 14/11, OTK A $2013 \mathrm{nr}$ 1, poz. 7.

18 Wyrok Trybunału Konstytucyjnego z dnia 12 lutego 2014 roku, sygn. K 23/10, OTK A $2014 \mathrm{nr} 2$, poz. 10.

19 Wyrok Trybunału Konstytucyjnego z dnia 23 listopada 2009 roku, sygn. P 61/08, OTK A $2009 \mathrm{nr} 10$, poz. 150. 
wość zasadnie oczekiwać, że prawodawca nie zmieni prawa w sposób arbitralny ${ }^{20}$, oczekiwać czytelności, przejrzystości, poszanowania zasad systemowych gwarantujących ochronę praw człowieka ${ }^{21}$. Prawodawca, którego działania mieszczą się w takim ujęciu racjonalności, unika zarzutu o arbitralność swoich działań22.

Rozważając utworzenie formy ochrony przyrody, w pierwszej kolejności należy zatem ustalić, czy spełniona została zawarta w odpowiednim upoważnieniu warunkowym przesłanka materialna do wydania odpowiedniego aktu wykonawczego, a jego wydanie jest przydatne dla osiągnięcia celu publicznego, jakim jest ochrona przyrody. Ustawa każdej z form ochrony przyrody przyporządkowuje określony stan faktyczny, który materialnie uprawnia do jej utworzenia. Dla przykładu, rezerwat przyrody obejmuje obszary zachowane w stanie naturalnym lub mało zmienionym, ekosystemy, ostoje i siedliska przyrodnicze, a także siedliska roślin, zwierząt i grzybów oraz twory i składniki przyrody nieożywionej wyróżniające się szczególnymi wartościami przyrodniczymi, naukowymi, kulturowymi lub walorami krajobrazowymi (art. 13 ust. 1 u.o.p.). W odniesieniu do pomników przyrody ogólne przesłanki materialne uregulowane są ustawowo (art. 40 ust. 1 u.o.p.), natomiast szczegółowe - rozporządzeniem Ministra Środowiska z dnia 4 grudnia 2017 roku w sprawie kryteriów uznawania tworów przyrody żywej i nieożywionej za pomniki przyrody ${ }^{23}$, który zgodnie z upoważnieniem ustawowym ma się kierować potrzebą ochrony drzew, krzewów i tworów przyrody nieożywionej (art. 40 ust. 3 u.o.p.).

Ustawodawca nie wymienił celów utworzenia formy ochrony przyrody ani z powodów dydaktycznych (lex imperet, non docet), ani uzasadniających, ale jako materialną granicę dopuszczalności wydania aktu wykonawczego. W akcie normatywnym nie zamieszcza się bowiem wypowiedzi, które nie służą wyrażaniu norm prawnych, a w szczególności apeli, postulatów, zaleceń, upomnień oraz uzasadnień formułowanych norm ( $§ 11$ rozporządzenia Prezesa Rady Ministrów z dnia 20 czerwca 2002 roku w sprawie Zasad techniki prawodawczej24, dalej: z.t.p.).

Oczywistym naruszeniem art. 94 ust. 1 Konstytucji byłoby wydanie aktu prawa miejscowego pomimo niespełnienia przesłanki materialnej, na przykład utworzenie rezerwatu przyrody na obszarze niewyróżniającym się szczególnymi wartościami przyrodniczymi, naukowymi, kulturowymi lub walorami krajobrazowymi. Sprzecznym z zasadą państwa prawnego byłoby również utworzenie formy ochrony przyrody w sytuacji, gdy powiązane z nią zakazy nie będą przydatne dla

20 Wyrok Trybunału Konstytucyjnego z dnia 14 kwietnia 2000 roku, sygn. P 3/00, OTK A $2000 \mathrm{nr}$ 5, poz. 138. Zob. także S. Wronkowska, Zasady..., s. 56.

21 Wyrok Trybunału Konstytucyjnego z dnia 12 kwietnia 2012 roku, sygn. SK 30/10, OTK A $2012 \mathrm{nr}, 431$ poz. 39.

22 Wyrok Trybunału Konstytucyjnego z dnia 12 lutego 2014 roku, sygn. K 23/10, OTK A $2014 \mathrm{nr}$ 2, poz. 10.

23 Dz.U. z 2017 r. poz. 2300.

24 Dz.U. z 2016 r. poz. 283. 
osiągnięcia celu prawodawcy, jakim jest ochrona przyrody ${ }^{25}$. Nie jest dopuszczalne tworzenie form ochrony przyrody w innych celach, na przykład jako dowodu uznania dla wartości przyrodniczej danego obszaru czy jego promocji.

Kontrola sądowa aktu tworzącego daną formę ochrony przyrody powinna zatem ustalić, czy jego ustanowienie na wyznaczonym obszarze zostało należycie udokumentowane pod względem chronionych ustawowo walorów przyrodniczych. Niezbędnym jest przy tym szczegółowe wykazanie, że na danej konkretnej działce znajdują się szczególnie cenne i wymagające ochrony wartości przyrodnicze $^{26}$. Ponieważ sąd administracyjny, co do zasady, nie może przeprowadzać postępowania dowodowego (art. $106 \S 3$ p.p.s.a.), to obowiązek w tym zakresie spoczywa na prawodawcy, który wydał zaskarżony akt ${ }^{27}$. Konieczne jest zwłaszcza przeprowadzenie aktualnych badań fauny i flory, albowiem przedawnione badania środowiskowe są nieprzydatne. Należy zgromadzić materiały, na przykład inwentaryzacje, opinie, ekspertyzy itp., które są niezbędne do określenia położenia formy ochrony przyrody ${ }^{28}$. Należy dostatecznie wykazać, że podlegające ochronie wartości przyrodnicze znajdują się na całym obszarze objętym formą ochrony przyrody. Odpowiednia dokumentacja musi być należyta, szczegółowa i nadająca się do kontroli sądowej ${ }^{29}$. W przeciwnym wypadku podjęty na jej podstawie akt wykonawczy będzie sprzeczny z prawem. Tylko dokładne wskazanie, co ma podlegać ochronie, może umożliwić dokonanie merytorycznej oceny aktu tworzącego formę ochrony przyrody ${ }^{30}$.

Choć istotnym źródłem informacji są opinie i wnioski osób fizycznych czy organizacji pozarządowych ${ }^{31}$, to jednak treści w nich zawarte muszą zostać zweryfikowane ${ }^{32}$ przez biegłego z zakresu ochrony środowiska, którego opinia wykaże spełnienie przesłanki materialnej do wydania danego aktu wykonawczego, a także przydatność odpowiednich ograniczeń dla ochrony przyrody. Przydatna jest także dokumentacja fotograficzna. Bez tego rodzaju „obiektywizacji” działanie prawodawcy byłoby arbitralne.

25 A. Królczyk, Glosa do wyroku NSA z 30 lipca 2010 r., II OSK 1053/10, „Gdańskie Studia Prawnicze. Przegląd Orzecznictwa" 2011, nr 1, s. 57.

26 Wyrok Naczelnego Sądu Administracyjnego z dnia 30 lipca 2010 roku, sygn. II OSK 1053/10, niepubl.

27 Wyrok Naczelnego Sądu Administracyjnego z dnia 5 lipca 2011 roku, sygn. II OSK 767/11, niepubl.

28 Wyrok Wojewódzkiego Sądu Administracyjnego w Olsztynie z dnia 28 września 2010 roku, sygn. II SA/Ol 451/10, niepubl.

29 Wyroki Wojewódzkiego Sądu Administracyjnego w Gliwicach z dnia 22 czerwca 2016 roku, sygn. II SA/Gl 253/16, niepubl. i z dnia 29 listopada 2013 roku, II SA/G1 1150/13, niepubl.

30 Wyrok Wojewódzkiego Sądu Administracyjnego w Gdańsku z dnia 14 sierpnia 2019 roku, sygn. II SA/Gd 239/19, niepubl.

31 S. Wronkowska, op. cit., s. 26.

32 Wyrok Wojewódzkiego Sądu Administracyjnego w Gdańsku z dnia 14 sierpnia 2019 roku, sygn. II SA/Gd 239/19, niepubl. 
Okoliczności faktyczne powodujące konieczność podjęcia aktu wykonawczego, w tym zwłaszcza uzasadniające przydatność, konieczność i proporcjonalność jego wydania, powinny zostać wymienione w uzasadnieniu tego aktu normatywnego. W szczególności z.t.p. wymagają, aby przedstawić możliwość podjęcia alternatywnych środków umożliwiających osiągnięcie zamierzonego celu ${ }^{33}$. W doktrynie akcentuje się, by uzasadnienie przedstawiało rzeczywisty stan w dziedzinie, która ma być unormowana, wskazywało cele, jakie zamierza się osiągnąć w danej dziedzinie i wykazywało, że cele te można i trzeba osiągnąć, wydając akt prawny. Należy ponadto wykazać, na jakich podstawach opiera się przekonanie, że projektowane normy okażą się zadowalająco skutecznymi, ekonomicznymi i trwałymi środkami oddziaływania ${ }^{34}$. Jednostki samorządu terytorialnego mogą regulować w statutach bardziej szczegółowe wymogi dotyczące uzasadniania swoich uchwał ${ }^{35}$.

\section{KONIECZNOŚĆ WYDANIA AKTU WYKONAWCZEGO}

Wydanie aktu prawnego koniecznie wymaga wykazania, że stan faktyczny wymaga interwencji organów władzy publicznej, a w szczególności — ustalenia, jakie niepokojące zjawiska dostrzega się w rozważanej dziedzinie. Następnie należy sformułować katalog możliwych do zastosowania środków, które mogłyby skutecznie służyć osiąganiu pożądanych zmian, w szczególności ekonomicznych, perswazyjnych, organizacyjnych, zmian sposobu interpretacji lub stosowania obowiązujących przepisów. Za zastosowaniem środków prawnych przemawiać muszą bowiem doniosłe racje ${ }^{36}$.

Wreszcie niezbędnym jest dokonanie wyboru środka $\mathrm{z}$ uwzględnieniem prawdopodobieństwa osiągnięcia zamierzonego celu, szybkości jego osiągnięcia, trwałości rezultatu, stopnia społecznej akceptacji dla proponowanych rozwiązań, możliwych niezamierzonych następstw ubocznych, skutków finansowych alternatywnych rozwiązań oraz możliwych źródeł ich pokrycia ${ }^{37}$. Racjonalny prawodawca wybiera cele służące najpełniejszej realizacji wyrażonego w Konstytucji systemu wartości, a następnie dobiera środki najbardziej adekwatne do realizacji tych celów $^{38}$. Środki zgodne z zasadą proporcjonalności to środki niezbędne, takie, które chronią określone wartości w sposób niemożliwy do osiągnięcia za pomocą

$33 \S 12$ w zw. z $\S 132$ i $\S 143$ z.t.p.

34 S. Wronkowska, op. cit., s. 52-53; Zasady tworzenia prawa, red. A. Michalska, S. Wronkowska, Poznań 1983, s. 33 i 35.

35 Art. 22 ust. 1 ustawy z dnia 8 marca 1990 roku o samorządzie gminnym, tekst jednia Dz.U. z 2018 r. poz. 994 ze zm., dalej jako u.s.g.; a także paralelne.

36 S. Wronkowska, op. cit., s. 25; a także Zasady tworzenia..., s. 39 i 43.

37 S. Wronkowska, op. cit., s. 27.

38 Wyrok Trybunału Konstytucyjnego z dnia 12 lutego 2014 roku, sygn. K 23/10, OTK A $2014 \mathrm{nr}$ 2, poz. 10. 
innych metod ${ }^{39} \mathrm{w}$ tym sensie, że chronić będą określone wartości w sposób lub w stopniu, który nie mógłby być osiągnięty przy zastosowaniu innych środków ${ }^{40}$.

Należy rozważyć także, jakie byłyby następstwa niepodjęcia działań prawodawczych (na przykład: czy wystapią niepowetowane straty, czy jest prawdopodobne, że nastąpi „samoregulacja” bez ingerencji prawodawcy). Jeśli dana dziedzina życia jest już uregulowana, konieczne jest ustalenie skutków wywieranych przez normy dotąd obowiązujące i określenie ich niedostatków ${ }^{41}$.

Przy tworzeniu formy ochrony przyrody niezbędne jest zatem ustalenie, czy wydanie takiego aktu jest konieczne dla realizacji celu publicznego, jakim jest ochrona przyrody. Ustanowienie formy ochrony przyrody nie może być bowiem pozostawione całkowitej uznaniowości i dowolności organów ${ }^{42}$. W szczególności zważyć trzeba, czy występują jakieś niepokojące zjawiska, czy nie da się ich usunąć za pomocą środków ekonomicznych lub perswazyjnych, oraz czy wystąpią niepowetowane straty.

Wykazać należy także, że tego celu publicznego nie zrealizuje inna, mniej restrykcyjna forma ochrony przyrody, a jeśli nie - czy wystarczającym jest ustanowienie części z dopuszczalnego katalogu zakazów. Jeżeli dany obszar jest już objęty niższą formą ochrony przyrody, należy uargumentować jej nieefektywność.

Uwzględnić należy też to, czy niezbędne jest ustanawianie ochrony obszarowej z racji występowania na danym obszarze roślin i zwierząt już objętych ochroną gatunkową ${ }^{43}$. To zadanie o tyle niełatwe, że większość gatunków, nawet pospolitych, znajduje się w Polsce pod ochroną gatunkową, a większość zwierząt niechronionych to gatunki łowne.

\section{ZAKAZ NADMIERNEJ INGERENCJI}

W przypadku konkurencyjności chronionych konstytucyjnie dóbr konieczne jest zachowanie przez prawodawce — tak na poziomie krajowym, jak lokalnym — czytelnej równowagi między interesami pozostającymi w kolizji ${ }^{44}$. Zakaz nadmiernej ingerencji jest rozumiany jako nakaz podejmowania środków adekwat-

39 Wyrok Trybunału Konstytucyjnego z dnia 9 października 2012 roku, sygn. P 27/11, OTK A $2012 \mathrm{nr}$ 9, poz. 104.

40 Wyrok Trybunału Konstytucyjnego z dnia 22 września 2005 roku, sygn. Kp 1/05, OTK A $2005 \mathrm{nr} 8$, poz. 93.

41 S. Wronkowska, op. cit., s. 26.

42 Wyrok Naczelnego Sądu Administracyjnego z dnia 30 lipca 2010 roku, sygn. II OSK 1053/10, niepubl.

43 Ibidem.

44 Wyrok Trybunału Konstytucyjnego z dnia 23 czerwca 2009 roku, sygn. K 54/07, Dz.U. z 2009 r. Nr 105, poz. 880. 
nych do założonych celów ${ }^{45}$. Należy zatem rozważyć, czy tego samego celu nie można było osiągnąć przy użyciu środków mniej uciążliwych dla obywatela, bo słabiej (bardziej płytko) ingerujących w sferę jego wolności i praw ${ }^{46}$. Jeżeli dany cel jest możliwy do osiągnięcia przy zastosowaniu innego środka, nakładającego mniejsze ograniczenia na prawa i wolności, to zastosowanie przez ustawodawcę środka bardziej uciążliwego wykracza poza to, co jest konieczne, a zatem narusza Konstytucję ${ }^{47}$. Dowolność i przypadkowość wprowadzanych w życie przepisów prawa jest bowiem złamaniem zasady państwa prawnego ${ }^{48}$. Prawodawca musi podejmować świadome decyzje $\mathrm{e}^{49}$.

Decyzję w sprawie podjęcia takich czy innych środków oddziaływania należy poprzedzić zasięgnięciem opinii podmiotów, które są zainteresowane rozstrzygnięciem. Służy to między innymi ustaleniu, czy projektowane rozwiązania naruszają czyjeś interesy; uzyskaniu wiedzy, którą dysponuja zainteresowane podmioty, a która dotyczy dziedziny spraw, w którą zamierza się interweniować; pozyskaniu wstępnej społecznej akceptacji dla zamierzonych zmian, co jest szczególnie potrzebne wtedy, gdy są one wprawdzie konieczne, ale niekorzystne dla zainteresowanych; oraz zapewnieniu gotowości współdziałania przy ich wprowadzeniu w życie ${ }^{50}$.

Nawet jeśli istnieją podstawy faktyczne i prawne do ustanowienia formy ochrony przyrody, a wydanie odpowiedniego aktu byłoby przydatne i konieczne dla realizacji celu publicznego, jakim jest ochrona przyrody, to konieczne jest ustalenie czy wydanie danego aktu w odpowiedniej formie jest zgodne z zakazem nadmiernej ingerencji. Konieczne jest szczegółowe wyważenie i uzasadnienie, czy właściwe cele publiczne uzasadniają ograniczenie prawa rzeczowego przysługującego właścicielom danych nieruchomości ${ }^{51}$. Obowiązkiem prawodawcy wydającego odpowiedni akt wykonawczy jest wykazanie i wyjaśnienie, dlaczego akurat ochrona danego obszaru jest na tyle istotna, że uzasadnia ograniczenie korzystania z nieruchomości52. Przesłanki i powody przyjęcia takiego stanowiska powinny być konkretne i odpowiednio uargumentowane. Będzie to zadanie tym

45 Wyrok Trybunału Konstytucyjnego z dnia 13 czerwca 2011 roku, sygn. SK 41/09, OTK A z 2011 roku nr 5, poz. 40.

46 Wyrok Trybunału Konstytucyjnego z dnia 12 stycznia 2000 roku, sygn. P 11/98, OTK 2000 nr 1, poz. 3.

47 Wyrok Trybunału Konstytucyjnego z dnia 23 czerwca 2009 roku, sygn. K 54/07, Dz.U. z 2009 r. Nr 105, poz. 880.

48 Wyrok Trybunału Konstytucyjnego z dnia 21 lutego 2006 roku, sygn. K 1/05, OTK A 2006 nr 2, poz. 18

49 S. Wronkowska, op. cit., s. 7.

50 S. Wronkowska, op. cit., s. 25-26.

51 Wyrok Naczelnego Sądu Administracyjnego z dnia 30 lipca 2010 roku, sygn. II OSK 1053/10, niepubl., wraz z glosą aprobującą A. Królczyk, „Casus” 2011, nr 1, s. 21.

52 Wyrok Wojewódzkiego Sądu Administracyjnego w Gdańsku z dnia 14 sierpnia 2019 roku, sygn. II SA/Gd 239/19, niepubl. 
trudniejsze, im szerszy będzie katalog zakazów ustanowionych spośród tych dopuszczalnych ustawowo ${ }^{53}$.

Konieczne jest również uzyskanie opinii właścicieli odpowiednich nieruchomości w celu uzyskania wiedzy na temat danego obszaru ${ }^{54}$. Mogą oni dysponować obszerną wiedzą odnośnie do swojej nieruchomości, w tym o jej walorach przyrodniczych, a także o rozmiarach szkody, jaką wyrządzi jej utworzenie danej formy ochrony przyrody. W obecnym stanie prawnym brak jest przepisu ustawowego zezwalającego na wejście na teren prywatny w celu dokonania oględzin w toku procesu prawodawczego, zatem właściciel nieruchomości może skutecznie się temu sprzeciwić 55 i zakwestionować - jako uzyskany niezgodnie z prawem - materiał dowodowy zebrany w trakcie oględzin bez jego zgody. Zasady przeprowadzania konsultacji przez jednostki samorządu terytorialnego określają uchwały organów stanowiących tych jednostek ${ }^{56}$.

\section{PRECYZYJNY ZASIĘG OBSZAROWY}

Ustawa wymaga także uregulowania zasięgu obszarowego danej formy ochrony przyrody. W odniesieniu do rezerwatu przyrody ma być to określenie położenia lub przebiegu granicy oraz otuliny (art. 13 ust. 3 u.o.p.), w odniesieniu do parku krajobrazowego - obszaru, przebiegu granicy i otuliny (art. 16 ust. 3 u.o.p.), w odniesieniu do obszaru chronionego krajobrazu — położenia i obszaru (art. 23 ust. 2 u.o.p.), a w odniesieniu do pozostałych form ochrony przyrody — położenia (art. 44 ust. 2 u.o.p.). Przepisy te - jak wszystkie inne - winny być zredagowane tak, aby dokładnie wyrażały intencje prawodawcy ${ }^{57}$, możliwie bezpośrednio i wyraźnie wskazywały kto, w jakich okolicznościach i jak powinien się zachować $^{58}$. Ta dyrektywa ogólna dotyczy zwłaszcza przepisów ograniczających konstytucyjne wolności lub prawa ${ }^{59}$, a zatem między innymi aktów tworzących formy ochrony przyrody. Przepisy muszą być formułowane w sposób poprawny, precyzyjny i jasny ${ }^{60}$. Nakaz określoności przepisów prawnych powinien być rozumiany

53 Wyrok Wojewódzkiego Sądu Administracyjnego w Krakowie z dnia 9 listopada 2011 roku, sygn. II SA/Kr 1486/11, niepubl.

54 K. Gruszecki, Ustawa o ochronie przyrody. Komentarz, Warszawa 2017, art. 44.

55 Art. $222 \S 2$ w zw. z art. 140 ustawy z dnia 23 kwietnia 1964 roku - Kodeks cywilny (Dz.U. z 2019 r. poz. 1145).

56 Art. 5a ust. 2 u. s. g. i paralelne

$57 \S 6 \mathrm{w} \mathrm{zW} . \mathrm{z} \S 132$ i $\S 143$ z.t.p.

$58 \S 25 \mathrm{w}$ zw. $\mathrm{z} \S 132 \mathrm{i} \S 143$ z.t.p.

59 Wyrok Trybunału Konstytucyjnego z dnia 30 października 2001 roku, sygn. K 33/00, OTK z 2001 r. nr 7, poz. 217.

${ }^{60}$ Wyrok Trybunału Konstytucyjnego z dnia 11 grudnia 2009 roku, sygn. Kp 8/09, OTK A 2009 nr 11, poz. 164. 
jako wymóg takiego ich formułowania, by zapewniały dostateczny stopień precyzji ich znaczenia i skutków prawnych i nie stanowiły pułapki dla obywateli61.

Ujęcie rozwiązań prawnych w sposób nieprecyzyjny, niejednoznaczny i powodujący istotne wątpliwości prawne oraz posługiwanie się pojęciami niezdefiniowanymi, nie może być uznane za poprawne z punktu widzenia zasad stanowienia prawa $^{62}$. Przepisy o niedookreślonej (niewystarczająco określonej) lub niezrozumiałej treści należy uznać za sprzeczne z zasadą państwa prawnego ${ }^{63}$. Przekroczenie pewnego poziomu niejasności przepisów prawnych może stanowić samoistną przesłankę stwierdzenia ich niezgodności z zasadą państwa prawnego ${ }^{64}$. Jeżeli prawodawca tworzy prawo zagmatwane i nieprecyzyjne, to szkodzi społeczeństwu ${ }^{65}$.

O ile obwarowanie danej formy ochrony przyrody odpowiednimi zakazami wymaga zaledwie wyboru $\mathrm{z}$ ustawowego katalogu zakazów, to doniosłym obowiązkiem prawodawcy tworzącego formę ochrony przyrody jest precyzyjne określenie jej granic terytorialnych ${ }^{66}$. Jest to o tyle istotne, że wprost wymagają tego ustawowe przepisy upoważniające. Niewątpliwie określenie położenia formy ochrony przyrody, w tym jej granic, ma bardzo istotne znaczenie dla właściciela gruntów, na których jest ona ustanowiona. Ma on prawo wiedzieć, na jakiej części swojego gruntu podlega ograniczeniom, a na jakich nie, szczególnie że jest zagrożony karami na wypadek niezastosowania się do ustanowionych ograniczeńn ${ }^{67}$.

Orzecznictwo, analizując określenie położenia użytku ekologicznego, wskazuje, że ,już chociażby określenie powierzchni »naokoło « świadczy o naruszeniu" wymogu precyzji prawa, a określenie granicy użytku na załączonej mapie w sposób niedokładny uchybia prawu ${ }^{68}$. Jako sposoby prawidłowego określenia granic w aktach tworzących formy ochrony przyrody wskazuje się: po granicach działek ewidencyjnych, przez określenie numerów działek, przez wskazanie punktów geodezyjnych, wreszcie po granicach naturalnych biegnących w terenie (na przykład rzeki, drogi) ${ }^{69}$. Pogląd ten wymaga, w ocenie autora, poczynienia kilku zastrzeżeń.

61 Wyrok Trybunału Konstytucyjnego z dnia 15 stycznia 2009 roku, sygn. K 45/07, OTK A $2009 \mathrm{nr} 1$, poz. 3.

62 Wyrok Trybunału Konstytucyjnego z dnia 17 grudnia 2002 roku, sygn. U 3/02, OTK A $2002 \mathrm{nr} 7$, poz. 95.

63 Wyrok Trybunału Konstytucyjnego z dnia 13 września 2005 roku, sygn. K 38/04, OTK A $2005 \mathrm{nr} 8$, poz. 92.

64 Wyrok Trybunału Konstytucyjnego z dnia 23 marca 2006 roku, sygn. K 4/06, OTK A 2006 nr 3, poz. 32 .

65 S. Wronkowska, op. cit., s. 7.

66 A. Lipiński, op. cit., s. 63.

67 Wyrok Wojewódzkiego Sądu Administracyjnego w Olsztynie z dnia 28 września 2010 roku, sygn. II SA/O1 451/10, niepubl.

68 Wyrok Wojewódzkiego Sądu Administracyjnego w Olsztynie z dnia 28 września 2010 roku, sygn. II SA/Ol 451/10, niepubl.

69 Wyrok Wojewódzkiego Sądu Administracyjnego w Olsztynie z dnia 28 września 2010 roku, sygn. II SA/Ol 451/10, niepubl. oraz wyrok Wojewódzkiego Sądu Administracyjnego w Gdańsku z dnia 14 sierpnia 2019 roku, sygn. II SA/Gd 239/19, niepubl. 
Po pierwsze, ustawa wyraźnie odróżnia pojęcia „położenia” oraz „przebiegu granicy" formy ochrony przyrody, polecając określenie położenia lub przebiegu granicy rezerwatu przyrody (art. 13 ust. 3 u.o.p), przebiegu granicy parku krajobrazowego (art. 16 ust. 3 u.o.p.), a wszystkich pozostałych — w tym użytku ekologicznego - położenia (art. 44 ust. 2 u.o.p.). Wynika to najprawdopodobniej z hipotezy, że większe obszarowo formy mają lub mogą być określane poprzez granice, natomiast mniejsze - przez położenie. Skoro zatem w przytaczanych orzeczeniach analizowano użytki ekologiczne, zatem formę objętą wymogiem określenia lokalizacji, odpadały formy określenia zasięgu obszarowego poprzez granice działek ewidencyjnych i po granicach naturalnych. W odniesieniu do tych ostatnich oraz punktów geodezyjnych wątpliwości budzi także to, czy ich używanie odpowiada na wymogi elastyczności prawa, która winna zapewniać adekwatność prawa do zmieniającej się rzeczywistości ${ }^{70}$.

Po drugie, określenie powierzchni formy ochrony przyrody jest obligatoryjne jedynie w odniesieniu do parku krajobrazowego i obszaru chronionego krajobra$\mathrm{zu}^{71}$, zatem przytoczenie ich „naokoło” w akcie tworzącym użytek ekologiczny nie może przesądzać o naruszaniu przezeń prawa.

Po trzecie, wymienianie granic działek nie przystaje do dyrektywy zwięzłego i syntetycznego redagowania przepisów ${ }^{72}$ oraz unikania formy opisowej ${ }^{73}$.

Konkludując, położenie formy ochrony przyrody można określić poprzez wskazanie jednego lub kilku numerów działek, które ma ona objąć. Zarówno jednak wtedy, jak i wówczas, gdy ustalić należy granice danej formy, pożądaną metodą jest mapa sytuacyjna ${ }^{74}$, od której należy oczekiwać możliwie wysokiej precyzji ${ }^{75}$.

\section{WNIOSKI}

Ustanowienie form ochrony przyrody musi następować w zgodności z zasadą państwa prawnego. W pierwszej kolejności konieczne jest zatem ustalenie i udokumentowanie (poprzez fotografie oraz opinie biegłego), czy spełniona została przesłanka materialna zawarta w odpowiednim upoważnieniu warunkowym. Następnie należy ustalić, czy utworzenie formy ochrony przyrody jest przydatne i konieczne dla ochrony przyrody i poszczególnych celów przypisanych przez ustawę konkretnej formie ochrony, a w szczególności czy nie wystarczą środki ekono-

70 S. Wronkowska, op. cit., s. 7.

71 Art. 16 ust. 3 i art. 23 ust. 2 u.o.p.

$72 \S 5 \mathrm{w}$ zW. $\mathrm{z} \S 132$ i $\S 143$ z.t.p.

73 Zasady tworzenia..., s. 68.

74 Wyrok Wojewódzkiego Sądu Administracyjnego w Gdańsku z dnia 14 sierpnia 2019 roku, sygn. II SA/Gd 239/19, niepubl.

75 Wyrok Wojewódzkiego Sądu Administracyjnego w Olsztynie z dnia 28 września 2010 roku, sygn. II SA/Ol 451/10, niepubl. 
miczne, perswazyjne, organizacyjne, zmiana sposobu interpretacji lub stosowania obowiązujących przepisów albo mniej dolegliwa forma ochrony lub mniejszy jej zakres terytorialny i takiż zakres zakazów. Ustalenia te winno się zawrzeć w uzasadnieniu odpowiedniego aktu wykonawczego. Redagując z kolei sam tekst aktu wykonawczego, konieczne jest precyzyjne ustalenie granic terytorialnych formy ochrony przyrody.

Fakt, że uwzględnione zostały wszystkie skargi na akty tworzące formy ochrony przyrody, które zawierały zarzut naruszenia zasady państwa prawnego, dowodzi, że zagadnienie to wymaga pogłębionej refleksji. Znalazło to wyraz $\mathrm{w}$ poglądach doktrynalnych postulujących ustandaryzowanie postępowań, w których dochodzi do ustanowienia form ochrony przyrody, na przykład poprzez wskazanie, na podstawie jakich konkretnie dowodów organ powinien dokonywać oceny, kiedy można uznać, że występują przesłanki do ustanowienia formy ochrony przyrody oraz jakie ograniczenia zapewniałyby skuteczną ochronę ${ }^{76}$. W ocenie autora do takich norm można by zaliczyć wymóg dokonania oględzin danego terenu przy obecności biegłego sądowego z zakresu ochrony środowiska, z których sporządzanoby protokół wraz $\mathrm{z}$ dokumentacją fotograficzną jeszcze przed wydaniem aktu wykonawczego. W zakresie tych czynności można by utworzyć odesłanie do przepisów Kodeksu postępowania administracyjnego. Można by też rozważyć określenie opinii jakich podmiotów rządowych i społecznych należy wymagać w zależności od przedmiotu ochrony danej formy. Należałoby określić wymóg oraz termin na uzyskanie opinii właściciela lub właścicieli nieruchomości, na których utworzona ma być forma ochrony przyrody. Rozważyć można także wprowadzenie obligatoryjnego udziału prokuratora $\mathrm{w}$ tym postępowaniu lub też zawiadamianie prokuratora o takim postępowaniu, gdyby organ uznał jego udział za potrzebny, podobnie jak ma to miejsce w postępowaniu administracyjnym (art. $183 \S 2$ ustawy z dnia 14 czerwca 1960 roku - Kodeks postępowania administracyjnego ${ }^{77}$ ).

\section{IMPLEMENTATION OF SOME PRINCIPLES OF CORRECT LEGISLATION WHEN CREATING SELECTED FORMS OF NATURE PROTECTION}

Summary

Establishing forms of nature protection must follow the principle of proper legislation. The purpose of this study is to determine how the lawmaker should implement this obligation. This includes the need to establish and document (through photographs and expert opinions) whether the material condition contained in the statutory authorization has been met. Next, are the forms of nature

76 K. Gruszecki, Glosa do wyroku NSA z dnia 17 grudnia 2015 r., II OSK 993/14, „Orzecznictwo w Sprawach Samorządowych" 2016, nr 4, s. 133.

77 Dz.U. z 2018 r. poz. 2096. 
protection available for the protection of nature and the specific forms of protection assigned by the act, and in particular whether economic, persuasive, organizational measures or a less painful form of protection or a smaller territorial scope and a smaller scope of prohibitions are not sufficient. It would be correct to include these provisions in the explanations for the relevant act of local law. It is necessary to precisely determine the territorial limitations of the form of nature protection.

Keywords: nature protection, proper legislation, decent legislation, proportionality, precision

\section{BIBLIOGRAFIA}

Gruszecki K., Glosa do wyroku NSA z dnia 17 grudnia 2015 roku, II OSK 993/14, „Orzecznictwo w Sprawach Samorządowych" 2016, nr 4.

Gruszecki K., Ustawa o ochronie przyrody. Komentarz, Warszawa 2017.

Królczyk A., Glosa do wyroku NSA z dnia 30 lipca 2010 roku, II OSK 1053/10, „Casus” 2011, nr 1.

Królczyk A., Glosa do wyroku NSA z dnia 30 lipca 2010 roku, II OSK 1053/10, „Gdańskie Studia Prawnicze. Przegląd Orzecznictwa” 2011, nr 1.

Lipiński A., Glosa do wyroku WSA z dnia 28 września 2010 roku, II SA/Ol 451/10, „Przegląd Prawa Ochrony Środowiska" 2012, nr 4.

Michalska A., Wronkowska S., Zasady tworzenia prawa, Poznań 1983.

Wronkowska S., Komentarz do zasad techniki prawodawczej, Warszawa 2012.

\section{ŹRÓDŁA}

Orzeczenie Trybunału Konstytucyjnego z dnia 26 kwietnia 1995 roku, sygn. akt K 11/94.

Wyrok Naczelnego Sądu Administracyjnego z dnia 30 lipca 2010 roku, sygn. akt II OSK 1053/10.

Wyrok Naczelnego Sądu Administracyjnego z dnia 5 lipca 2011 roku, sygn. akt II OSK 767/11.

Wyrok Trybunału Konstytucyjnego z dnia 12 stycznia 2000 roku, sygn. akt P 11/98.

Wyrok Trybunału Konstytucyjnego z dnia 14 kwietnia 2000 roku, sygn. akt P 3/00.

Wyrok Trybunału Konstytucyjnego z dnia 30 października 2001 roku, sygn. akt K 33/00.

Wyrok Trybunału Konstytucyjnego z dnia 17 grudnia 2002 roku, sygn. akt U 3/02.

Wyrok Trybunału Konstytucyjnego z dnia 18 stycznia 2005 roku, sygn. akt K 15/03.

Wyrok Trybunału Konstytucyjnego z dnia 13 września 2005 roku, sygn. akt K 38/04.

Wyrok Trybunału Konstytucyjnego z dnia 22 września 2005 roku, sygn. akt Kp 1/05.

Wyrok Trybunału Konstytucyjnego z dnia 21 lutego 2006 roku, sygn. akt K 1/05.

Wyrok Trybunału Konstytucyjnego z dnia 23 marca 2006 roku, sygn. akt K4/06.

Wyrok Trybunału Konstytucyjnego z dnia 15 stycznia 2009 roku, sygn. akt K 45/07.

Wyrok Trybunału Konstytucyjnego z dnia 23 czerwca 2009 roku, sygn. akt K 54/07.

Wyrok Trybunału Konstytucyjnego z dnia 23 listopada 2009 roku, sygn. akt P 61/08.

Wyrok Trybunału Konstytucyjnego z dnia 11 grudnia 2009 roku, sygn. akt Kp 8/09.

Wyrok Trybunału Konstytucyjnego z dnia 13 czerwca 2011 roku, sygn. akt SK 41/09.

Wyrok Trybunału Konstytucyjnego z dnia 12 kwietnia 2012 roku, sygn. akt SK 30/10.

Wyrok Trybunału Konstytucyjnego z dnia 9 października 2012 roku, sygn. akt P 27/11.

Wyrok Trybunału Konstytucyjnego z dnia 31 stycznia 2013 roku, sygn. akt K 14/11.

Wyrok Trybunału Konstytucyjnego z dnia 12 lutego 2014 roku, sygn. akt K 23/10.

Wyrok Wojewódzkiego Sądu Administracyjnego w Olsztynie z dnia 28 września 2010 roku, sygn. akt II SA/Ol 451/10.

Wyrok Wojewódzkiego Sądu Administracyjnego w Krakowie z dnia 9 listopada 2011 roku, sygn. akt II SA/Kr 1486/11. 
Wyrok Wojewódzkiego Sądu Administracyjnego w Gliwicach z dnia 29 listopada 2013 roku, sygn. akt II SA/Gl 1150/13.

Wyrok Wojewódzkiego Sądu Administracyjnego w Gliwicach z dnia 22 czerwca 2016 roku, sygn. akt II SA/G1 253/16.

Konstytucja Rzeczypospolitej Polskiej z dnia 2 kwietnia 1997 roku (Dz.U. z 1997 r. Nr 78, poz. 483).

Ustawa z dnia 23 kwietnia 1964 roku — Kodeks cywilny (Dz.U. z 2020 r. poz. 1740).

Ustawa z dnia 8 marca 1990 roku o samorządzie gminnym (Dz.U. z 2020 r. poz. 713).

Ustawa z dnia 27 lipca 2001 roku — Prawo o ustroju sądów powszechnych (Dz.U. z 2020 r. poz. 2072).

Ustawa z dnia 30 sierpnia 2002 roku — Prawo o postępowaniu przed sądami administracyjnymi (Dz.U. z 2019 r. poz. 2325).

Ustawa z dnia 16 kwietnia 2004 roku o ochronie przyrody (Dz.U. z 2020 r. poz. 55).

Rozporządzenie Prezesa Rady Ministrów z dnia 20 czerwca 2002 roku w sprawie „Zasad techniki prawodawczej" (Dz.U. z 2016 r. poz. 283).

Rozporządzenie Ministra Środowiska z dnia 4 grudnia 2017 roku w sprawie kryteriów uznawania tworów przyrody żywej i nieożywionej za pomniki przyrody (Dz.U. z 2017 r. poz. 2300). 